\title{
Pengolahan Sinyal EMG sebagai Perintah Kontrol untuk Kursi Roda Elektrik
}

\author{
Jeffry Glen Sitanaya, Tasripan, Achmad Arifin \\ Departemen Teknik Elektro, Fakultas Teknologi Elektro, \\ Institut Teknologi Sepuluh Nopember \\ e-mail: tasripan@ee.its.ac.id
}

\begin{abstract}
Abstrak - Kursi roda elektrik merupakan salah satu alat bantu yang bisa digunakan untuk menunjang mobilitas seseorang yang mengalami kelumpuhan pada bagian kaki. Pada umumnya kontroller pada kursi roda elektrik menggunakan joystick. Tetapi penggunaan joystick sulit untuk orang yang telah lanjut usia dan orang yang menderita kuadriplegia. Oleh sebab itu dilakukan penelitian mengenai pengolahan sinyal elektromiografi (EMG) sebagai perintah kontrol untuk kursi roda elektrik. Sinyal EMG diakuisisi dengan menggunakan rangkaian instrumentasi EMG. Hasil sinyal yang didapatkan dari rangkaian instrumentasi lalu diproses oleh mikrokontroller dan dikirim ke laptop untuk memonitor sinyal otot dan memberikan perintah kontrol pada kursi roda elektrik. Hasil rata-rata persentase keberhasilan sistem untuk perintah kontrol maju sebesar $89.33 \%$, perintah kontrol belok kiri $97.33 \%$, belok kanan $97.33 \%$, dan berhenti $100 \%$.
\end{abstract}

Kata kunci-Elektromiografi (EMG), Kelumpuhan, Kursi Roda Elektrik, Mikrokontroller.

\section{PENDAHULUAN}

$\mathrm{K}$ ELUMPUHAN merupakan keadaan yang menyebabkan penderita tersebut tidak mampu untuk melakukan pergerakan pada otot kaki ataupun otot tangan. Kelumpuhan disebabkan karena adanya cedera pada bagian sistem saraf pusat [1][2]. Selain cedera pada sistem saraf pusat, kelumpuhan juga disebabkan oleh penyakit tertentu seperti stroke, cedera spinalis, multiple sclerosis, serebral palsi, sindrom paska-polio, dan lain-lain [3].

Seseorang yang mengalami kelumpuhan pada bagian kaki dapat menggunakan kursi roda untuk meunjang mobilitasnya dalam melakukan aktivitas sehari-harinya. Hingga saat ini sudah didesain suatu kursi roda elektrik dengan menggunakan joystick sebagai pengendalinya. Tetapi penggunann joystick sulit digunakan untuk orang yang sudah lanjut usia dan orang yang menderita kuadriplegia [4],[5].

Oleh sebab itu dilakukan penelitian dengan mengimplentasikan penggunaan biosignal pada otot tangan sebagai perintah kontrol pada kursi roda elektrik. Sebelumnya telah dilakukan penelitian yang serupa dengan menggunakan biosignal contohnya seperti yang dilakukan oleh Chung Sing Louis Tsui dkk (2008) menggunakan kombinasi dari EMG dan EEG untuk menggerakan kursi roda, Biswajeet dkk (2014) dengan menggunakan gerak jari untuk mengontrol gerakan prototipe kursi roda, dan Sathish kk (2016) menggunakan gerakan otot untuk mengontrol gerakan prototipe kursi roda.

Pada penelitan ini diimplementasikan penggunaan biosignal pada otot lengan bawah sebagai perintah kontrol pada kursi roda elektrik. Informasi dari biosignal tersebut digunakan untuk memberikan perintah kontrol berupa perintah maju, berhenti, belok kiri dan belok kanan pada kursi roda elektrik. Dengan pengimplentasian biosignal pada kursi roda elektrik ini, diharapkan mobilitas individu tersebut menjadi lebih mudah.

\section{METODE PENELITIAN}

\section{A. Elektromiografi $(E M G)$}

Elektromiografi (EMG) merupakan teknik untuk memeriksa dan merekan sinyal pada otot. Cara kerja elektromiografi dengan mendeteksi potensial listrik yang dihasilkan oleh sel otot ketika otot berkontraksi dan ketika otot berelaksasi. Otot akan menghasilkan arus listrik yang proporsional dengan tingkat aktifitas otot. EMG akan menerjemahkan sinyal-sinyal ini ke dalam bentuk grafik, suara, atau nilai-nilai numerik yang dapat diinterprestasikan untuk memahami kesehatan otot[6]. Amplitudo yang dihasilkan oleh EMG bergantung kepada faktor-faktor seperti penempatan elektroda dan jenis elektroda yang digunakan[7].

\section{B. Rangkaian Instrumentasi EMG}

Rangkaian Instrumentasi EMG digunakan sebagai pemroses sinyal biolelektrik untuk mengetahui aktifitas sinyal yang disebabkan oleh aktifitas otot[8][9][10]. Rangkaian instrumentasi EMG terdiri dari high pass filter dengan frekuensi cutoff $1 \mathrm{~Hz}$, rangkaian penguat instrumentasi EMG dengan penguatan $2300 \mathrm{kali}$, bandpass filter dengan rentang frekuensi $50 \mathrm{~Hz}-500 \mathrm{~Hz}$ dengan penguatan $3 \mathrm{kali}$, low pass filter dengan frekuensi cutoff $1 \mathrm{~Hz}$, dan main amplifier. Gambar 1 merupakan desain dari rangkaian instrumentasi EMG.

\section{STM32F4 Discovery}

STM32F4 Discovery digunakan sebagai mikrokontroller dalam penelitian ini. STM32F4 merupakan seri pertama dari STM32 dengan berbasis ARM Cortex-M4F 32 bit. STM32F4 ini berbasis mikrokontroller STM32F407VG. Pada mikrokontroller ini juga telah termasuk ST-LINK/V2 yang merupakan embedded debug, dua ST-MEMS digital akselerometer, digital mikrofon, satu audio DAC yang terintegrasi dengan kelas D driver speaker, LED, tombol, dan konektor USB OTG micro-AB. STM32F4 mempunyai clock sebesar $168 \mathrm{MHz}$. STM32F4 juga mempunyai fitur seperti ADC, PWM, Timer, DMA, USART, dan lain-lain[11]. Pada penelitian ini STM32F4 Discovery berfungsi untuk memproses sinyal EMG yang diperoleh dari rangkaian instrumentasi EMG, melakukan pengiriman data secara serial ke laptop, dan menghasilkan sinyal PWM untuk mengontrol pergerakan kursi roda elektrik. Pada penelitian ini Timer Period pada STM32F4 Discovery diatur sebesar $2 \mathrm{kHz}$ menyesuaikan dengan frekuensi sampling yang digunakan. Hasil pengiriman serial lalu ditampilkan pada program Delphi di laptop. 


\section{Delphi}

Delphi pada penelitian ini digunakan untuk memonitor sinyal otot. Pada Delphi terdapat program bandpass filter yang terdiri dari low pass filter dengan frekuensi cutoff $500 \mathrm{~Hz}$ dan high pass filter digital dengan frekuensi cutoff $50 \mathrm{~Hz}$ dan program moving average dan squaring untuk mempermudah penentuan perintah kontrol pada kursi roda elektrik. Gambar 2 merupakan desain interface pada Delphi di laptop.

\section{E. Kursi Roda Elektrik}

Kursi roda Jet 3 Ultra merupakan kursi roda elekrik yang diproduksi oleh Pride Mobility Product Corp. Untuk menggerakkan kursi roda ini terdapat beberapa pin kontrol yang harus dihubungkan dengan PWM dari mikrokontroller. Pin ground pada kursi roda elektrik harus dijadikan satu dengan pin ground dari mikrokontroller. Kursi roda elektrik mampu beban hingga berat maksimal $136 \mathrm{~kg}$.

\section{F. Blok Diagram Sistem}

Gambar 3 merupakan diagram blok dari penelitian ini secara keseluruhan yang terdiri dari rangkaian instrumentasi EMG yang digunakan untuk menangkap sinyal otot pada saat kontraksi dan relaksasi, mikrokontroller STM32F4 Discovery yang digunakan untuk memproses sinyal otot yang diperoleh dari rangkaian instrumentasi EMG, melakukan pengiriman data secara serial ke laptop, dan menghasilkan sinyal PWM untuk mengontrol pergerakan kursi roda elektrik.

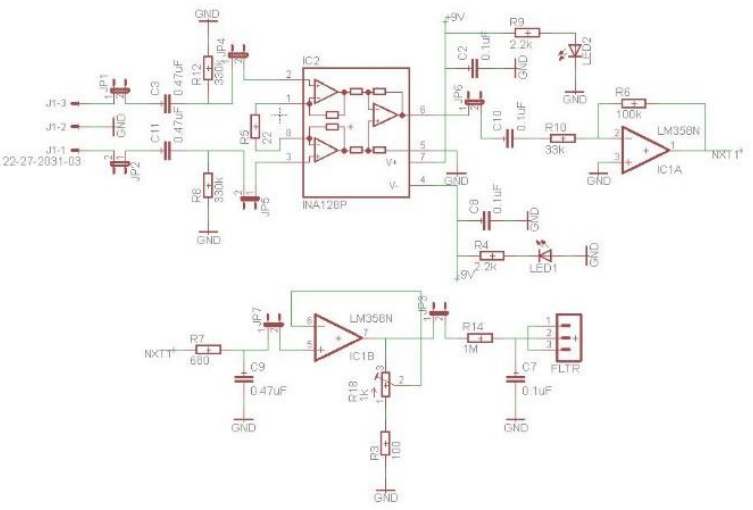

Gambar 1. Rangkaian instrumentasi EMG.

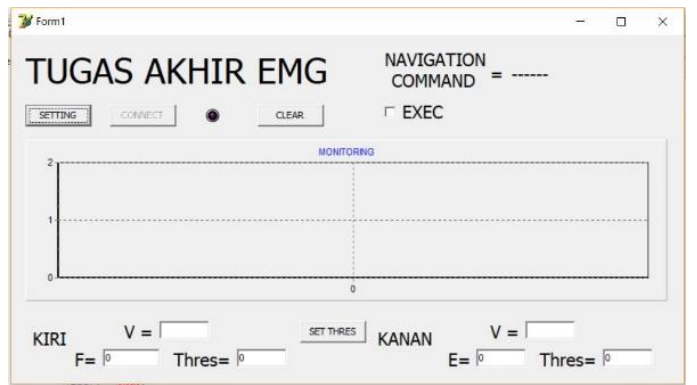

Gambar 2. Desain interface pada Delphi.

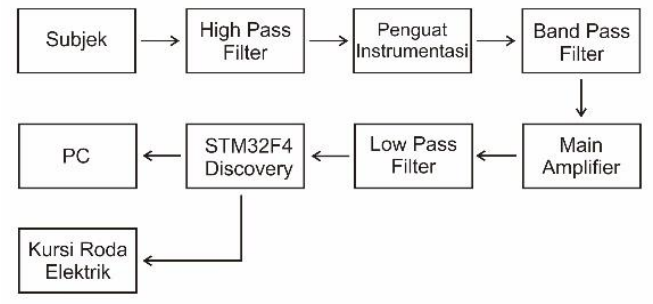

Gambar 3. Diagram blok sistem secara keseluruhan.

\section{HASIL PENGUJIAN DAN ANALISA}

\section{A. Pengujian Perangkat Keras}

Pengujian perangkat keras merupakan pengujian pada rangkaian instrumentasi EMG. Pengujian dilakukan dengan cara subjek duduk secara rileks pada kursi roda elektrik dan melakukan kontraksi dan relaksasi pada tangan kanan dan tangan kiri untuk memberikan perintah kontrol kursi roda elektrik sesuai dengan perintah dari peneliti. Pada penelitian ini elektroda diletakkan pada bagian otot Fleksor Carpi Radialis dikarenakan pada otot tersebut merupakan bagian yang sensitif pada saat otot berkontraksi dan berelaksasi. Gambar 4 merupakan contoh peletakan elektroda pada otot Fleksor Carpi Radialis.

Pada saat tangan kiri relaksasi diperoleh Vpp sebesar 140 $\mathrm{mV}$ dan pada saat kontraksi diperoleh Vpp sebesar $420 \mathrm{mV}$. Sedangkan saat tangan kanan relaksasi diperoleh nilai Vpp sebesar $120 \mathrm{mV}$ dan pada saat tangan kanan kontraksi diperoleh nilai Vpp sebesar $300 \mathrm{mV}$. Gambar 5a merupakan hasil sinyal EMG yang terbaca pada osiloskop saat tangan kiri kontraksi dan relaksasi dan Gambar 5b merupakan hasil sinyal otot yang terbaca pada saat tangan kanan kontraksi dan relaksasi.

\section{B. Pengujian Perangkat Lunak}

Pada pengujian perangkat lunak terdiri dari pengujian keluaran sinyal PWM dari STM32F4 Discovery dan pengujian filter digital pada Delphi. Untuk pengujian keluaran sinyal PWM dari STM32F4 Discovery dilakukan dengan cara melihat hasil keluaran sinyal PWM pada osiloskop. Pada pengujian ini digunakan pin B4, B5, B6, dan B7 pada STM32F4 Discovery sebagai pin keluaran PWM. Pengujian dilakukan dengan menggunakan duty cycle sebesar $37 \%, 84 \%$, dan $90 \%$. Ketiga nilai PWM tersebut digunakan untuk mengontrol gerakan dari kursi roda elektrik. Gambar 6a, 6b, 6c merupakan hasil keluaran sinyal PWM dengan duty cycle 37\%, 84\%, dan 90\%.

Untuk pengujian filter digital terdiri dari pengujian low pass filter dan high pass filter. Pada penelitian ini didesain filter digital low pass filter dengan frekuensi cutoff $500 \mathrm{~Hz}$ dan high pass filter dengan frekuensi cutoff $50 \mathrm{~Hz}$. Pengujian filter digital low pass filter dilakukan dengan cara diberi masukan sinyal sinus dengan Vpp $1.32 \mathrm{~V}$ dengan frekuensi $100 \mathrm{~Hz}-$ $1000 \mathrm{~Hz}$ pada pin C1 STM32F4 Discovery dan dilihat hasil sinyal keluarannya pada Delphi. Gambar 7 merupakan hasil plot pengujian low pass filter dengan frekuensi cutoff $500 \mathrm{~Hz}$. Sedangkan pengujian high pass filter dengan cara diberi masukan sinyal sinus dengan Vpp $1.32 \mathrm{~V}$ dan frekuensi $10 \mathrm{~Hz}$ - $100 \mathrm{~Hz}$ pada pin C1 STM32F4 Discovery dan dilihat hasil sinyal keluarannya pada Delphi. Gambar 8 merupakan hasil plot pengujian high pass filter dengan frekuensi cutoff $50 \mathrm{~Hz}$.
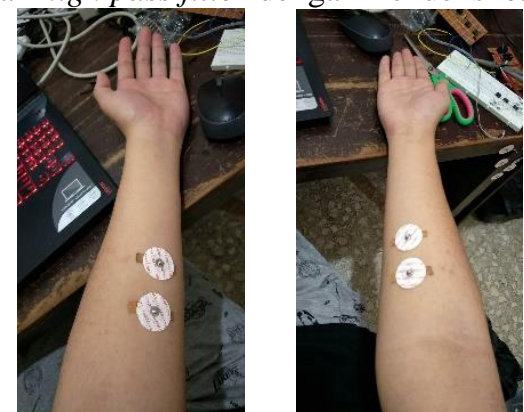

Gambar 4. Posisi peletakkan elektroda pada otot fleksor Carpi Radialis. 


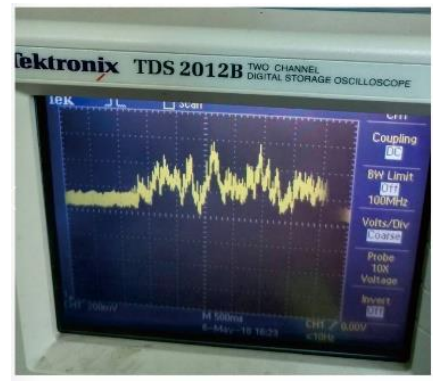

(a)

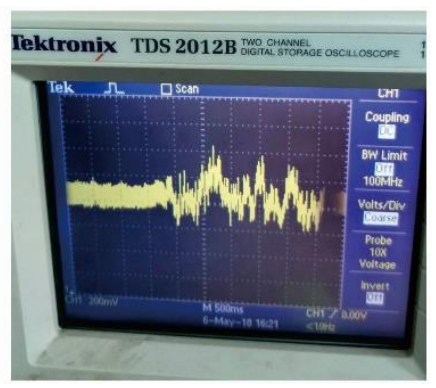

(b)
Gambar 5. (a) Sinyal EMG saat tangan kiri kontraksi dan relaksasi (b) Sinyal EMG saat tangan kanan kontraksi dan relaksasi.

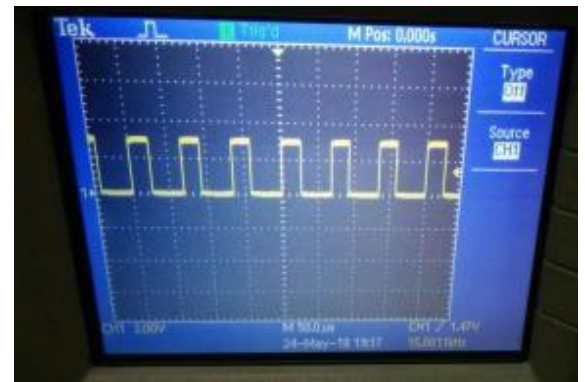

(a)

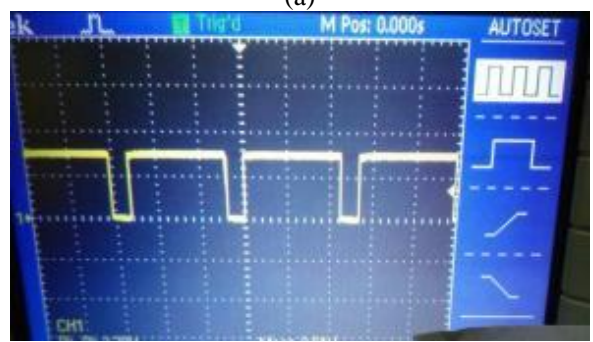

(b)

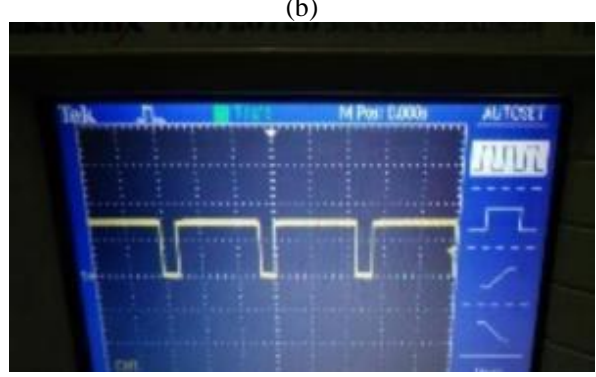

(c)

Gambar 6. (a) Hasil keluaran PWM dengan duty cycle 37\%, (b) Hasil keluaran PWM dengan duty cycle $84 \%$, (c) Hasil keluaran PWM dengan duty cycle $90 \%$.

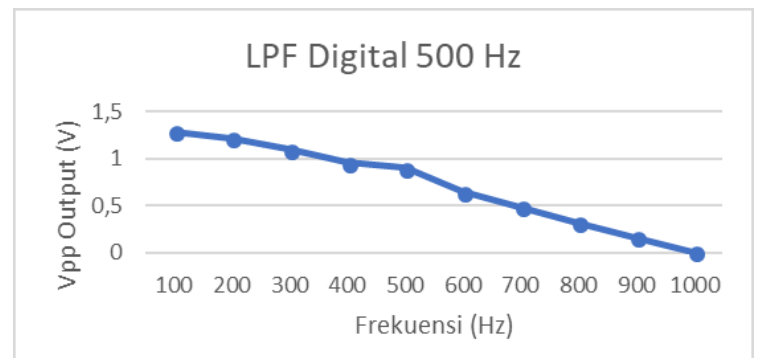

Gambar 7. Hasil plot filter digital Low Pass Filter dengan frekuensi Cutoff 500 $\mathrm{Hz}$.

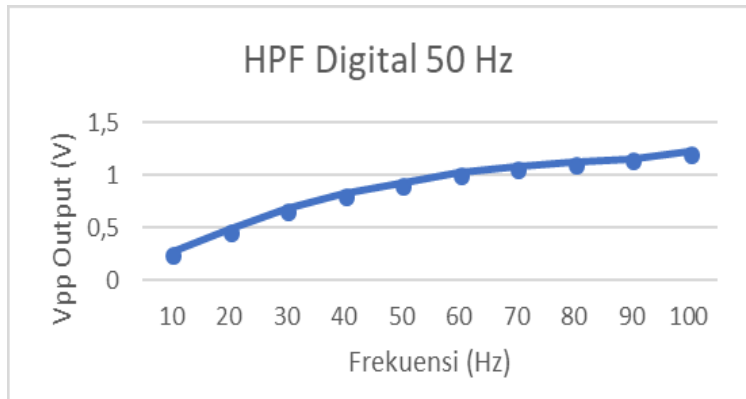

Gambar 8. Hasil plot filter digital High Pass Filter dengan frekuensi Cutoff 50 $\mathrm{Hz}$.

\section{Pengujian Penggabungan Perangkat Keras dan Perangkat Lunak}

Pengujian ini dilakukan sama dengan pengujian perangkat keras yaitu dengan cara subjek duduk secara rileks pada kursi roda dan melakukan kontraksi dan relaksasi otot tangan kanan dan kiri sesuai dengan arahan dari peneliti. Gambar 9 merupakan contoh pengambilan data pada subjek. Untuk perintah kontrol belok kanan maka tangan kiri subjek dalam keadaan relaksasi sedangkan tangan kanan dalam keadaan kontraksi seperti Gambar 10a. dan untuk perintah kontrol belok kiri maka tangan kiri dalam keadaan kontraksi sedangkan tangan kanan dalam keadaan relaksasi seperti pada Gambar 10b. Untuk perintah kontrol maju maka kedua tangan subjek harus dalam keadaan kontraksi seperti Gambar 11a dan untuk perintah kontrol diam kedua tangan dalam keadaan relaksasi seperti Gambar $11 \mathrm{~b}$.

Tabel 1 merupakan tegangan yang terukur pada Delphi saat kontraksi dan relaksasi untuk tangan kanan dan kiri pada ketiga subjek. Dari Tabel tersebut terdapat perbedaan tegangan saat tangan kanan dan tangan kiri melakukan kontraksi dan relaksasi. Perbedaan tegangan tersebut dapat dibuat suatu tegangan threshold untuk menentukan perintah kontrol pada kursi roda elektrik. Gambar 12 merupakan contoh hasil pembacaan sinyal pada subjek saat perintah kontrol belok kanan dan Gambar 13 merupakan contoh hasil pembacaan sinyal pada subjek saat perintah kontrol belok kiri. Sinyal dengan warna biru merupakan pembacann sinyal otot pada tangan kanan dan sinyal dengan warna hijau merupakan pembacaan sinyal otot pada tangan kiri. Pengujian pada subjek dilakukan sebanyak lima kali untuk tiap perintah kontrol dan Tabel 2 merupakan persentase keberhasilan pada ketiga subjek untuk tiap perintah kontrol. Dari pengujian tersebut diperoleh kecepatan saat maju dan belok kanan sebesar $0.74 \mathrm{~km} / \mathrm{jam}$, belok kiri dengan kecepatan sebesar $1.47 \mathrm{~km} /$ jam, belok kiri dengan sudut kemiringan sebesar 30 derajat dan belok kanan dengan sudut kemiringan sebesar 10 derajat. Dari ketiga pengujian subjek tersebut dapat diperoleh nilai rata-rata keberhasilan untuk tiap perintah kontrol. Tabel 3 merupakan hasil rata-rata persentase keberhasilan tiap perintah kontrol dan Tabel 4 menunjukkan spesifikasi alat pada penelitian ini. 


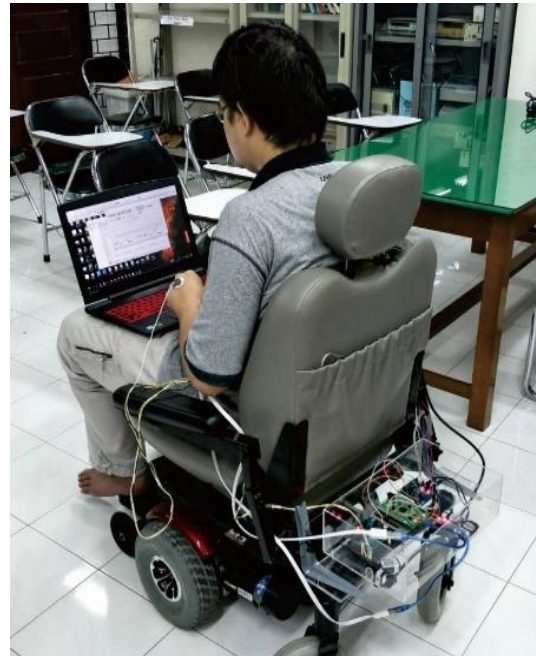

Gambar 9. Metode pengambilan data pada subjek.

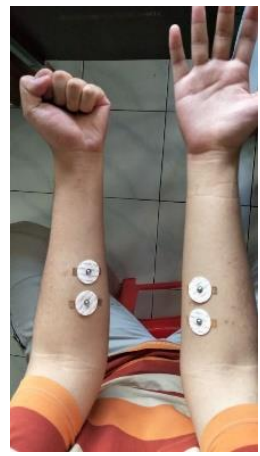

(a)

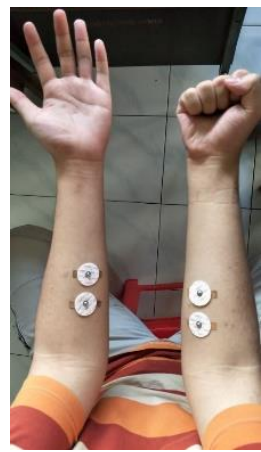

(b)
Gambar 10. (a) Contoh gerakan tangan untuk perintah belok kiri dan (b) Contoh gerakan tangan untuk perintah belok kanan.

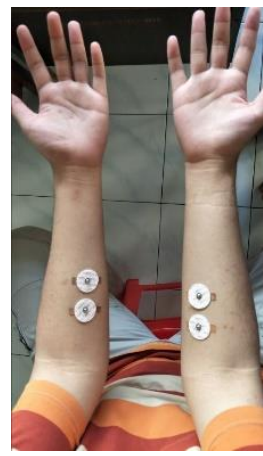

(a)

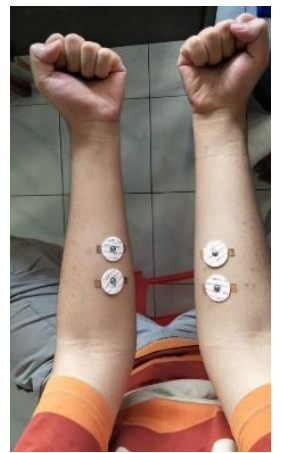

(b)
Gambar 11. (a) Contoh gerakan tangan untuk perintah diam dan (b) Contoh gerakan tangan untuk perintah maju.

Tabel 1.

Hasil Pembacaan Sinyal Otot Pada Delphi

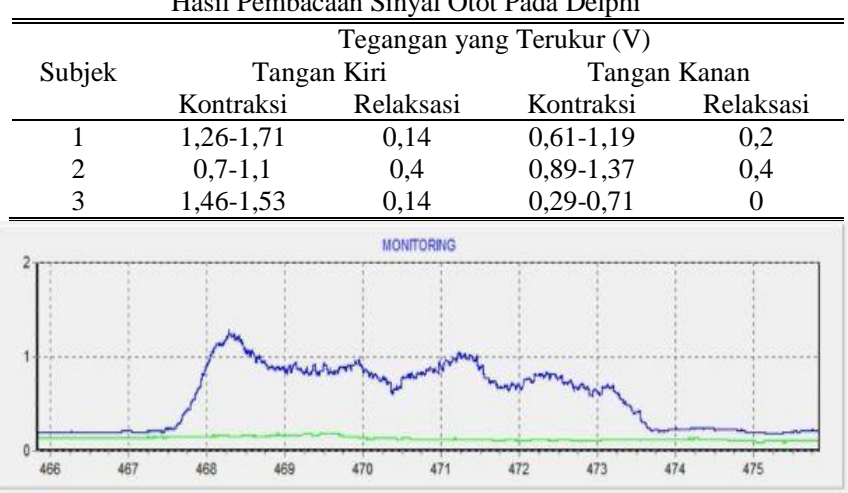

Gambar 12. Hasil pembacaan sinyal untuk perintah kontrol belok kanan.

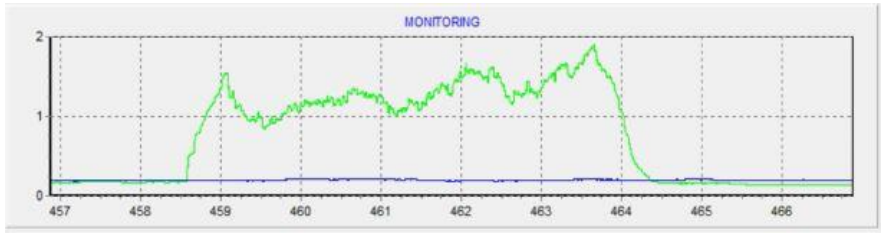

Gambar 13. Hasil pembacaan sinyal untuk perintah kontrol belok kiri.

Tabel 2.

Persentase keberhasilan tiap perintah kontrol pada ketiga subjek

\begin{tabular}{ccccc}
\hline \hline \multirow{2}{*}{ Subjek } & \multicolumn{4}{c}{ Persentase Keberhasilan Tiap Perintah Kontrol (\%) } \\
& Maju & Belok Kiri & Belok Kanan & Diam \\
\hline 1 & 84 & 100 & 92 & 100 \\
2 & 88 & 92 & 100 & 100 \\
3 & 96 & 100 & 100 & 100 \\
\hline \hline
\end{tabular}

Tabel 3.

Rata-rata keberhasilan tiap perintah kontrol

\begin{tabular}{lc}
\hline \hline Perintah Kontrol & Rata-rata Persentase Keberhasilan Tiap Perintah \\
Kontrol (\%)
\end{tabular}

\section{Perbandingan Alat dan Hasil Dengan Penelitian Sebelumnya}

Hasil perbandingan alat antara penelitian ini dengan penelitian dan produk yang lain yaitu harga dari sensor EMG yang digunakan lebih murah dibandingkan dengan produk modul sensor yang sudah ada seperti MyoWare Muscle Sensor Kit, pada penelitian ini digunakan kursi roda elektrik sungguhan sedangkan pada beberapa penelitian yang lain menggunakan prototipe sebagai pengganti kursi roda elektrik, dan hasil penelitian telah diujikan pada beberapa subjek dan diperoleh rata-rata persentase keberhasilan untuk perintah kontrol maju, belok kiri, dan belok kanan mendekati $100 \%$ dan untuk perintah kontrol berhenti rata-rata persentase keberhasilan sebesar $100 \%$ sedangkan untuk penelitian yang lain tidak diujikan pada subjek dan penentuan berhasil atau tidaknya penelitian tersebut hanya sebatas mampu untuk menggerakan prototipe kursi roda saja.

\section{KESIMPULAN DAN SARAN}

Pada paper ini dilakukan penelitian mengenai pengolahan sinyal EMG sebagai perintah kontrol untuk kursi roda elektrik. Pada penelitian ini terdiri rangkaian instrumentasi EMG, mikrokontroller STM32F4 Discovery, dan kursi roda elektrik. Rangkaian instrumentasi EMG mempunyai penguatan total 6900 kali. Mikrokontroller STM32F4 Discovery digunakan untuk memproses sinyal EMG yang diperoleh dari rangkaian instrumentasi, melakukan pengiriman data ke laptop untuk memonitor sinyal otot, dan menghasilkan sinyal PWM untuk menggerakan kursi roda elektrik. Kursi roda elektrik yang 
mampu menahan beban dengan berat maksimal $136 \mathrm{~kg}$, maju dan belok kanan dengan kecepatan $0.74 \mathrm{~km} / \mathrm{jam}$, belok kiri dengan kecepatan $1.47 \mathrm{~km} /$ jam, belok kiri dengan kemiringan sudut sebesar 30 derajat, dan belok kanan dengan kemiringan sudut sebesar 10 derajat. Pada penelitian ini elektroda diletakkan pada bagian otot Fleksor Carpi Radialis dikarenakan bagian otot tersebut merupakan bagian yang sensitif pada saat otot kontraksi dan relaksasi. Pengujian dilakukan pada tiga subjek dan diperoleh nilai rata-rata persentase keberhasilan untuk perintah kontrol maju sebesar $89.33 \%$, perintah kontrol belok kiri $97.33 \%$, belok kanan $97.33 \%$, dan berhenti $100 \%$.

Untuk penelitian selanjutnya dapat didesain filter yang mampu meredam dari gerakan kabel elektroda karena pergerakan kabel mempengaruhi sinyal EMG dan meningkatkan sensitifitas dari EMG untuk mendeteksi sinyal otot.

\section{DAFTAR PUSTAKA}

[1] Anon Human physiology : From Cells to Systems

[2] Jeong-Su Han, Zenn Bien Z, Dae-Jin Kim, Hyong-Euk Lee and JongSung Kim Human-machine Interface for Wheelchair Control with EMG and Its Evaluation Proceedings of the 25th Annual International
Conference of the IEEE Engineering in Medicine and Biology Society (IEEE Cat. No.03CH37439) (IEEE) pp 1602-5

[3] Anon Adams and Victor's Principles of Neurology

[4] Sathish S, Nithyakalyani K, Vinurajkumar S, Vijayalakshmi C and Sivaraman J 2016 Control of Robotic Wheel Chair using EMG Signals for Paralysed Persons Indian J. Sci. Technol. 9

[5] Chun Sing Louis Tsui, Jia P, Gan J Q, Hu H and Yuan K 2007 EMGbased Hands-free Wheelchair Control with EOG Attention Shift Detection 2007 IEEE International Conference on Robotics and Biomimetics (ROBIO) (IEEE) pp 1266-71

[6] Liou J-C, Shih T-T, Lin W-C and Huang Y-C 2015 Noninvasive ECG and EMG Electrode System for Health Monitoring and Science Technology Application 2015 IEEE International Conference on Consumer Electronics - Taiwan (IEEE) pp 102-3

[7] Phinyomark A, Limsakul C and Phukpattaranont P 2011 A Review of Control Methods for Electric Power Wheelchairs Based on Electromyography Signals with Special Emphasis on Pattern Recognition IETE Tech. Rev. $\mathbf{2 8} 316$

[8] Fu J, Chen J, Shi Y and Li Y 2013 Design of A Low-Cost Wireless Surface EMG Acquisition System 2013 6th International IEEE/EMBS Conference on Neural Engineering (NER) (IEEE) pp 699-702

[9] Sanchez D R, Velasquez L and Camargo L H 2013 Design of A EMG Wireless Surface EMG 6 Channels 2013 ISSNIP Biosignals and Biorobotics Conference: Biosignals and Robotics for Better and Safer Living (BRC) (IEEE) pp 1-6

[10] Wang J, Tang L and E Bronlund J 2013 Surface EMG Signal Amplification and Filtering Int. J. Comput. Appl. 82 15-22

[11] STMicroelectronics RM0090 Reference Manual 